\title{
A family with diaphyseal aclasis and peripheral dysostosis
}

\author{
A P BROOKS AND RUTH WYNNE-DAVIES
}

From the Ipswich Hospital, Anglesea Road Wing, Ipswich, Suffolk, and the Department of Orthopaedic Surgery (Clinical Genetics), University of Edinburgh, Edinburgh

SUMMARY Autosomal dominant inheritance of a type of peripheral dysostosis occurred in a family with diaphyseal aclasis. The features of their type of peripheral dysostosis were short limbed short stature, normal intelligence, very stubby fingers, flat face and nose, shortened metacarpals and terminal phalanges, thickened beaten-copper skull vault, and advanced skeletal maturation.

In the $\mathbf{M}$ family illustrated in fig 1 the female index patient III.3 had features of diaphyseal aclasis inherited as an autosomal dominant trait from her father II.3, whose own mother I.2 was also affected. When III.3 was seen with her mother II.4 the similarity of their facial features, hands, and body proportions was noted. Investigation showed the mother to have a type of peripheral dysostosis, and her two daughters III. 3 and III. 4 had features of both diaphyseal aclasis and peripheral dysostosis. The index patient's maternal grandmother I.4 died aged 74 years of a cerebrovascular accident and was approximately $147 \mathrm{~cm}$ tall; she probably also had peripheral dysostosis.

Received for publication 1 November 1979
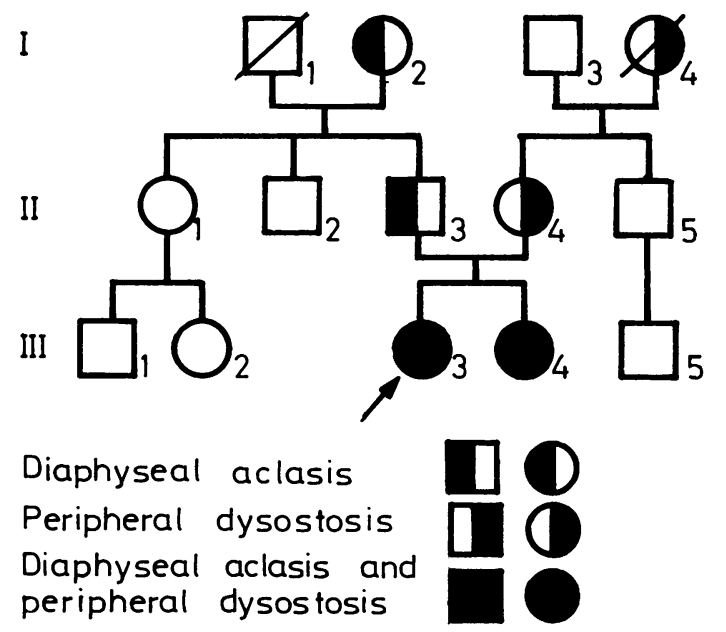

FIG 1 Pedigree of the $M$ family.

\section{Case report}

The female index patient III.3 presented to an endocrine clinic at the age of 14 years 4 months with short stature (height $129 \mathrm{~cm}$, below $-2 \mathrm{SD}$ ). Physical and mental development were otherwise normal, and she had begun to menstruate the previous year. She drew attention to a bony swelling at the lower end of her left femur which was limiting knee flexion, and radiology indicated diaphyseal aclasis with a typical cartilage capped exostosis on the distal femur as well as at the lower end of the radius and ulna, proximal femora, and pelvis. On further examination she was noted to have a large skull with a flat face and nose and very short stubby fingers and toes.

Radiologically the skull vault was thickened with a beaten-copper appearance, and the terminal phalanges and metacarpals (except for the second ray) were shortened. There was advanced skeletal maturation with all epiphyses in the hand and wrist fused by the age of 14 years 4 months. At the age of 18 years 1 month she had finished growing and had the body measurements shown in the table, indicating short limbed short stature.

The clinical and radiological features of the $M$ family are listed in the table and illustrated in fig 2 and 3.

\section{Discussion}

This family is of interest since two distinct skeletal dysplasias inherited by autosomal dominant genes are segregating together.

In the form of peripheral dysostosis seen here the phenotype is typified clinically by short limbed short stature, normal intelligence, very short stubby 
TABLE Clinical and radiological features of the 4 members of family $M$

\begin{tabular}{|c|c|c|c|c|c|c|c|c|c|c|}
\hline \multirow[t]{2}{*}{ Case } & \multirow[t]{2}{*}{ Age } & \multirow{2}{*}{$\begin{array}{l}\text { Bone } \\
\text { age }\end{array}$} & \multirow{2}{*}{$\begin{array}{l}\text { Standing } \\
\text { height } \\
(\mathrm{cm})\end{array}$} & \multirow{2}{*}{$\begin{array}{l}\text { Arm } \\
\text { span } \\
(\mathrm{cm})\end{array}$} & \multirow{2}{*}{$\begin{array}{l}\text { Head to } \\
\text { pubi.s } \\
(\mathrm{cm})\end{array}$} & \multirow{2}{*}{$\begin{array}{l}\text { Pubis to } \\
\text { heel } \\
(\mathrm{cm})\end{array}$} & \multicolumn{2}{|c|}{ Wiberg's* CE angle } & \multirow[t]{2}{*}{ Appearance } & \multirow{2}{*}{$\begin{array}{l}\text { Radiological } \\
\text { diagnosis }\end{array}$} \\
\hline & & & & & & & $\boldsymbol{R}$ & $L$ & & \\
\hline II .3 & 45 yr $4 \mathrm{mth}$ & Adult & $\begin{array}{l}152 \cdot 4 \\
\text { (Ht v span }\end{array}$ & $\begin{array}{l}142 \cdot 3 \\
1 \cdot 07)\end{array}$ & $\begin{array}{lr}88 \cdot 0 & 7 \\
\text { (Ratio } & 1 \cdot 26)\end{array}$ & $70 \cdot 0$ & $\begin{array}{l}24^{\circ} \\
(36-24)\end{array}$ & $\begin{array}{l}28^{\circ} \\
(36-24)\end{array}$ & $\begin{array}{l}\text { Short; normal } \\
\text { hands, skull, face }\end{array}$ & Diaphyseal aclasis \\
\hline II. 4 & 47 yr $4 \mathrm{mth}$ & Adult & $\begin{array}{l}137 \cdot 2 \\
\text { (Ht v span } 1\end{array}$ & $\begin{array}{l}127 \cdot 1 \\
1 \cdot 08)\end{array}$ & $\begin{array}{lr}75 \cdot 0 & 6 \\
\text { (Ratio } & 1 \cdot 17)\end{array}$ & $64 \cdot 0$ & $\begin{array}{l}31^{\circ} \\
(37-28)\end{array}$ & $\begin{array}{l}38^{\circ} \\
(38-27)\end{array}$ & $\begin{array}{l}\text { Short; stubby } \\
\text { fingers; large skull; } \\
\text { flat face }\end{array}$ & Peripheral dysostosis \\
\hline JII.3 & $18 \mathrm{yr} 1 \mathrm{mth}$ & Adult & $\begin{array}{l}130 \cdot 2 \\
\text { (Ht v span }\end{array}$ & $\begin{array}{l}121 \cdot 0 \\
1 \cdot 08)\end{array}$ & $\begin{array}{lr}69 \cdot 8 & 6 \\
\text { (Ratio } & 1 \cdot 15)\end{array}$ & $60 \cdot 9$ & $\begin{array}{l}20^{\circ} \\
(35-25)\end{array}$ & $\begin{array}{l}13^{\circ} \\
(34-20)\end{array}$ & $\begin{array}{l}\text { Short; large } \\
\text { exostosis left knee; } \\
\text { stubby fingers; } \\
\text { large skull; flat face }\end{array}$ & $\begin{array}{l}\text { Diaphyseal aclasis } \\
\text { and peripheral } \\
\text { dysostosis }\end{array}$ \\
\hline III.4 & $13 \mathrm{yr} 9 \mathrm{mth}$ & $16 \mathrm{yr}$ & $\begin{array}{l}132 \cdot 1 \\
(\mathrm{Ht} \text { v span }\end{array}$ & $\begin{array}{l}123 \cdot 2 \\
1 \cdot 07)\end{array}$ & $\begin{array}{l}72 \cdot 3 \\
\text { (Ratio }\end{array}$ & $63 \cdot 5$ & $\begin{array}{l}21^{0} \\
(34-24)\end{array}$ & $\begin{array}{l}27^{0} \\
(33 \cdot 5- \\
19 \cdot 5)\end{array}$ & $\begin{array}{l}\text { Short; stubby } \\
\text { fingers; large skull; } \\
\text { flat face; left } \\
\text { acetabular dysplasia }\end{array}$ & $\begin{array}{l}\text { Diaphyseal aclasis } \\
\text { and peripheral } \\
\text { dysostosis }\end{array}$ \\
\hline
\end{tabular}

* The figures in brackets show the mean and -2 SD values for CE angle, which varies with age, side, and sex.

fingers and toes, a flat face and nose, and a large skull, as illustrated in fig 2 , and with the radiological features shown in fig 3.

The father, II.3, with diaphyseal aclasis alone, had short stature, a normal skull, and a short right ourth metacarpal. Short stature may be a feature of diaphyseal aclasis and the bones of the hand are commonly involved, but a short metacarpal is not known to be a typical feature. ${ }^{12}$ The mother, II.4, had short limbed short stature, which in this type of peripheral dysostosis is perhaps the result of the advanced skeletal maturation with early fusion of epiphyses as found in III.3 and III.4.

Peripheral dysostosis is an ill-defined condition. It should be distinguished from acromesomelic dwarfism $^{3}$ in which forearm bones are also shortened and inheritance is probably autosomal recessive. A syndrome of acrodysostosis has been described by Robinow et al, ${ }^{4}$ with short stature, mental deficiency, nasal hypoplasia, and peripheral dysostosis. While the bone changes in the hands are similar to those in the $\mathbf{M}$ family, the facial changes are more severe $\vec{\oplus}$ in acrodysostosis, warranting the term 'pug-nose', and all cases described have been sporadic. A number of cases reported under the heading 'peripheral dysostosis' have been included in this congenital malformation syndrome.

In type $\mathrm{E}$ brachydactyly ${ }^{5}$ affected subjects have a $\frac{\circ}{\varnothing}$ round face and short stature, but the metacarpals are principally shortened, and the phalanges to a iesser extent than in the type of peripheral dysostosis seen here.

Bachman $^{6}$ described a family with autosomal dominant inheritance of a type of peripheral

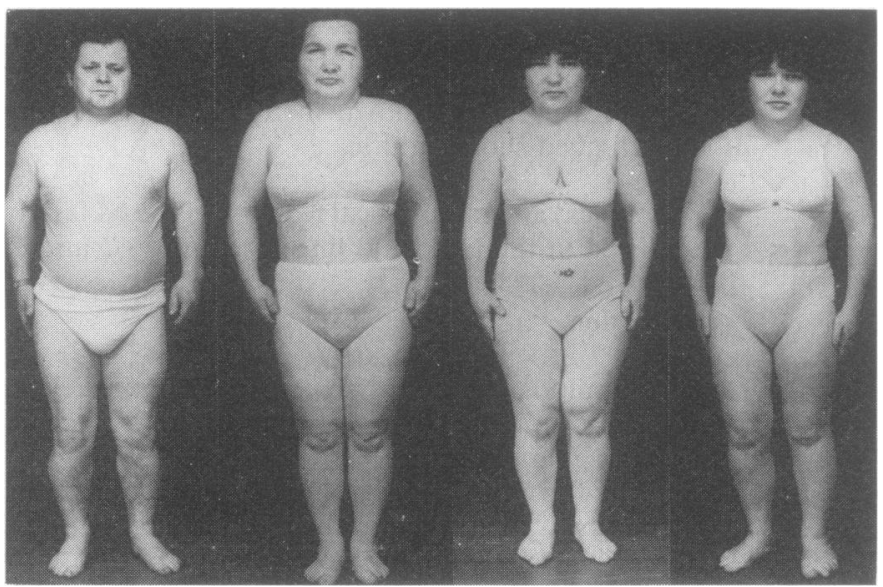

FIG 2a Whole body views of father, mother index patient, and sister. 

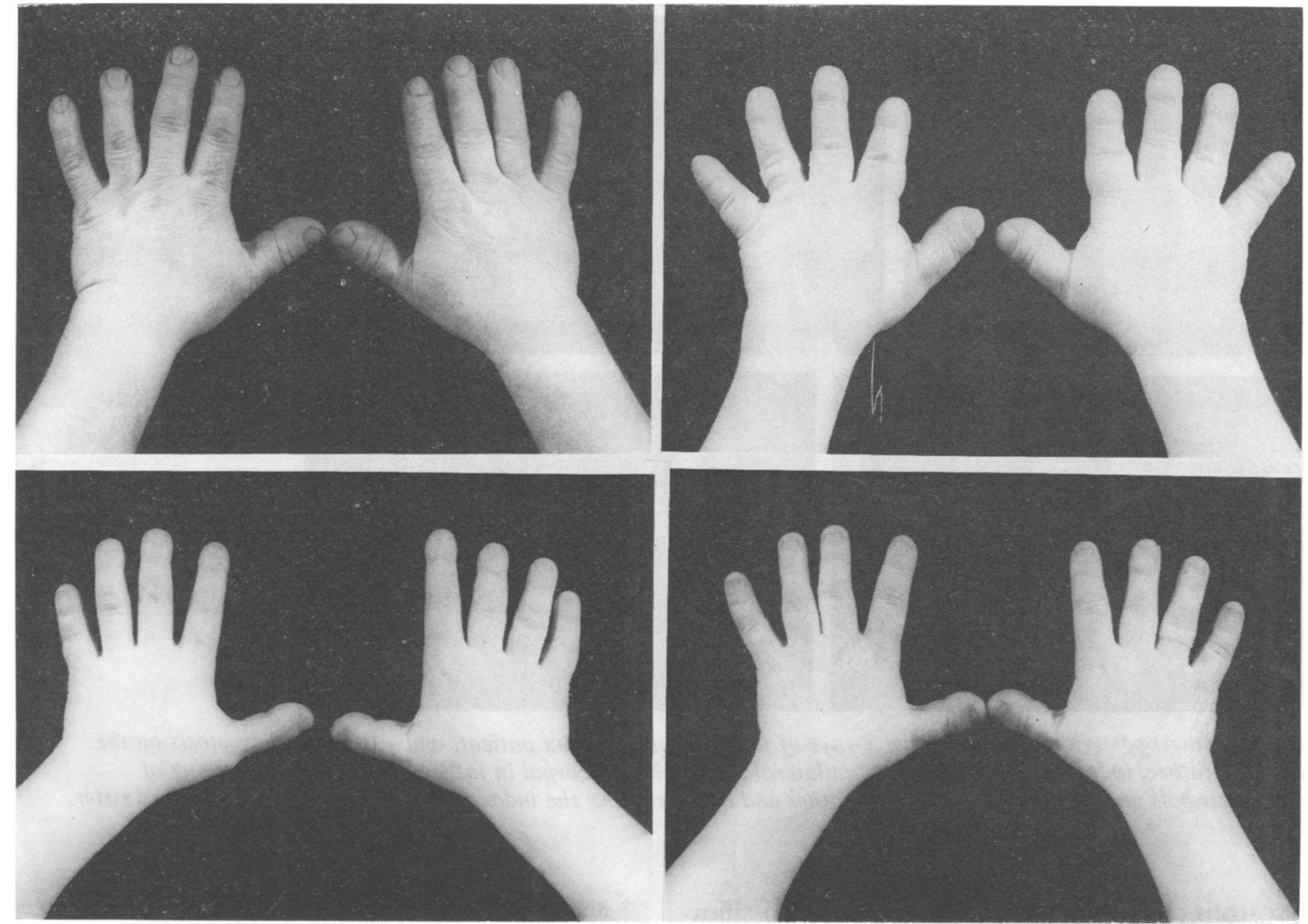

FIG $2 \mathrm{~b}$ Hands of father, mother, index patient, and sister. Note particularly metacarpals and terminal phalanges in mother, index patient, and sister.
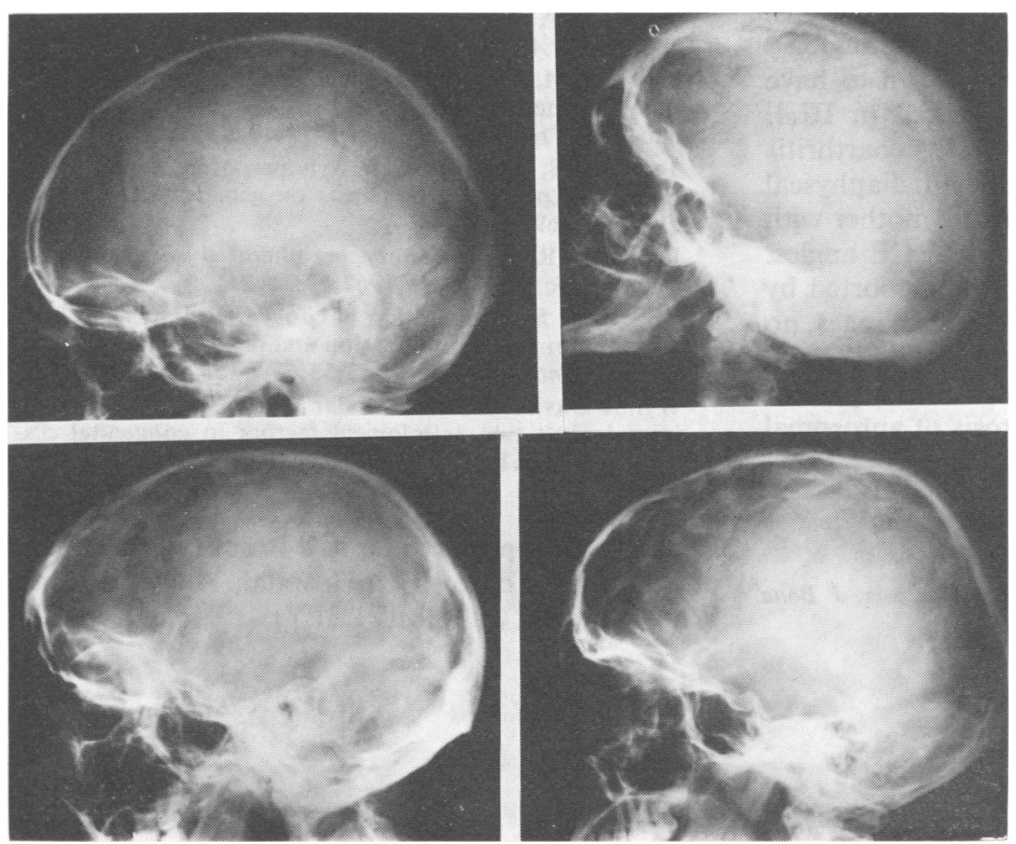

FIG 3a Lateral skull $x$-rays of father, mother, index patient, and sister. Note thickening of vault and beaten-copper appearance in all but father. 


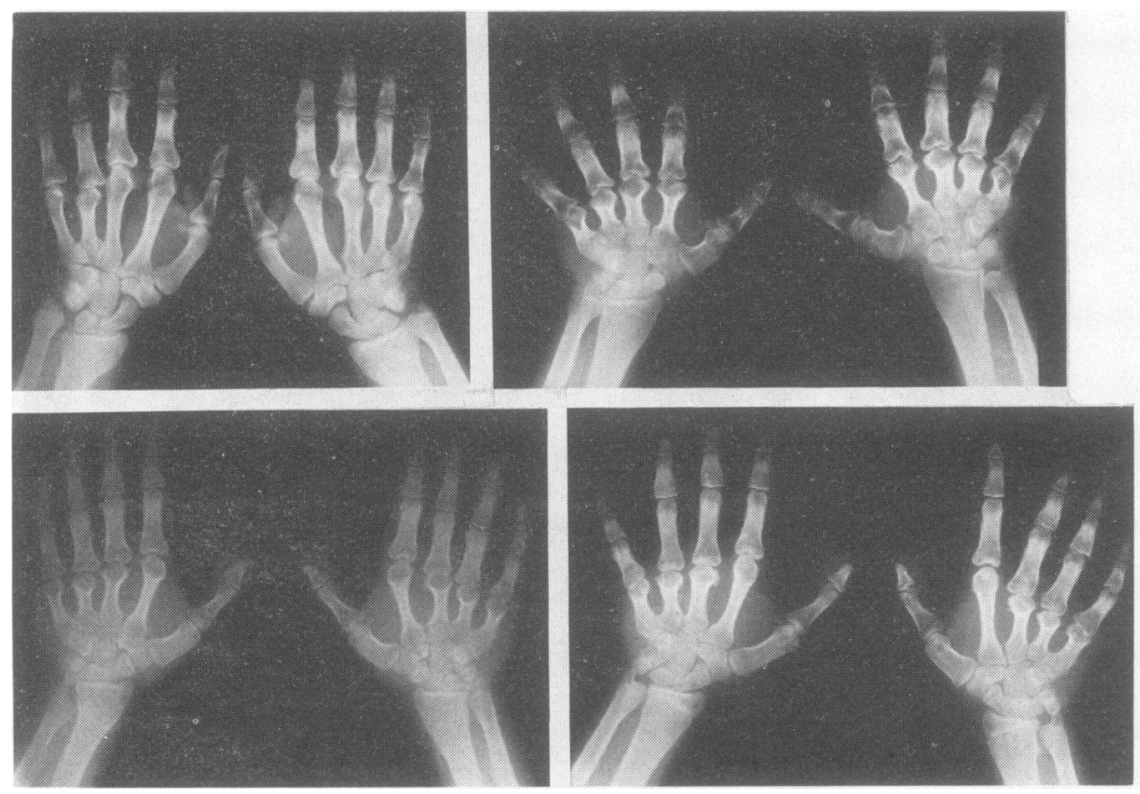

FIG 3b Anteroposterior hand and wrist $x$-rays of father, mother, index patient, and sister. Note exostosis on the radius of father, index patient, and sister, unilateral short 4th metacarpal in father, very severe shortening of all metacarpals and terminal phalanges in mother and also, omitting the index finger, in the index patient and sister.

dysostosis characterised by marked delay in ossification of the bones of the hands and hyperextensibility and hyperflexibility of the fingers, in which the mother also had severe osteoarthritic destruction of the hips. In the $\mathrm{M}$ family, using Wiberg's $\mathrm{CE}$ angle, ${ }^{78}$ the father and both daughters were shown to have acetabular dysplasia, particularly marked in III.4, and this could well progress to severe osteoarthritis at a later age. These members all had diaphyseal aclasis involving the pelvis, whereas the mother with peripheral dysostosis alone had normal CE angles. The $\mathbf{M}$ family further differs from that reported by Bachman in that the members have skull changes, no finger joint abnormality, and advanced skeletal maturity in the hands. They therefore must represent a distinct type of peripheral dysostosis of autosomal dominant inheritance.

\section{References}

1 Solomon L. Bone growth in diaphysial aclasis. $J$ Bone Joint Surg (Br) 1961;43:700-16.
2 Solomon L. Hereditary multiple exostoses. $J$ Bone Joint Surg (Br) $1963 ; 45: 292-304$

3 Langer LO, Beals RK, Solomon L, Bard PA, Bard LA, Rissman EM, Rogers JG, Dorst JP, Hall JG, Sparkes RS, $\overrightarrow{\bar{D}}$ Franken EA. Acromesomelic dwarfism: manifestations in childhood. Am J Med Genet 1977;1:87-100.

4 Robinow M, Pfeiffer RA, Gorlin RJ, et al. Acrodysostosis. A syndrome of peripheral dysostosis, nasal hypoplasia and mental retardation. Am J Dis Child 1971 ;121 :195-203.

5 Temtamy S, McKusick VA. Synopsis of hand malformations with particular emphasis on genetic factors. Birth Defects 1969;5:125-84.

${ }^{6}$ Bachman RK. Hereditary peripheral dysostosis (three cases). Proc $R$ Soc Med 1967;60:21-2.

7 Wiberg G. Shelf operation in congenital dysplasia of the acetabulum and in subluxation and dislocation of the hip. J Bone Joint Surg (Am) 1953;35:65-80.

8 Wynne-Davies R. Acetabular dysplasia and familial $\frac{T}{O}$ joint laxity: two aetiological factors in congenital dislocation of the hip.J Bone Joint Surg (Br) 1970;52:704-16. N

Requests for reprints to Dr A P Brooks, Department of Medicine, The Ipswich Hospital, Anglesea Road $\frac{\omega}{\sigma}$ Wing, Ipswich, Suffolk IP1 3PY. 